\title{
Role and Responsibilities of Notary Statement on General Meeting of Shareholders (AGM)
}

\author{
Yuli Tri Yana*), Amin Purnawan**), and Widhi Handoko**) \\ *) Student of Master of Notary Law, Universitas Islam Sultan Agung (UNISSULA) \\ Semarang, E-Mail: fathir.elvio@gmail.com \\ ${ }^{* *}$ Lecturer of Master of Notary Law, Universitas Islam Sultan Agung (UNISSULA) \\ Semarang \\ ${ }^{* * *}$ Lecturer of Master of Notary Law, Universitas Islam Sultan Agung (UNISSULA) \\ Semarang
}

\begin{abstract}
The purpose of this study was to determine: 1) The powers and responsibilities of Notaries in deed statement of decision general meeting of shareholders of a limited liability company, 2) The legal consequences of a deed statement of decision general meeting of shareholders of a limited liability company, 3) Legal protection for Notaries in the making deed of declaration decision general meeting of shareholders limited liability company. The approach used in this paper is normative, with the help of primary data in the form of legal material which is two primary legal materials and secondary legal materials as the main data. The data collection was obtained by interview and literature. The data were analyzed qualitatively normative. The research results are: 1). Role of Notary in the manufacture of the Deed of General Meeting of Shareholders of the Company Limited by Act No. 30 of 2004 concerning Notary, particularly Article 15 which essentially gives some authority to the Notary as a public official in performing their duties, namely: Notary authorized to make an authentic deed regarding all deeds, agreements, and provisions required by legislation and / or desired by the stakeholders to be stated in an authentic deed, deed of guarantee certainty of the date of manufacture, save deed, giving grosse, copy, and official copies, all of it along the manufacture the deed was not also be assigned or excluded to other officials or any other person specified by law. 2). General Meeting of Shareholders. 3). Deed of the General Meeting of shareholders is an authentic act that is Partij Akten that deed made by the parties before a notary.
\end{abstract}

Keywords: Responsibilities; Notary; Statement; Shareholders. 


\section{Introduction}

Various forms of Companies in Indonesia such as firms, Guild Commanditaire, cooperatives, limited liability company and so forth, but in the business world the most desirable form of business is a limited liability business entities. Limited Company is a legal entity forms the most desirable. Almost every person or business actors who have the capital to invest middleclass or doing business with the basic legality of legal entities in form Company Limited. That is because Responsibilities of shareholders at the Company Limited was limited to the amount of shares held, so if something happens or bankruptcy on the Company Such personal wealth is not mixed with Limited Liability Company.

Company Limited is a partnership that is a legal entity, where the legal entity is referred to as "the company". The term of the company in a limited liability company, referring to the method of determining the capital in a legal entity, which consists of stock or shares, while the term limited pointed to limit the responsibility of the limited company or shareholders, which is limited to the total nominal value of all shares owned. ${ }^{1}$

In this case the legal materials into one that is required to support the development of national economy of Indonesia, the Basic Law of Limited Liability Company Act No. 40 of 2007 on Limited Liability force since 16 August 2007, replacing Act No. 1 of 1995 on Limited Liability Company,

Act No. 40 of 2007 on Limited Liability Company (Company Law) to put a notary at a high position, this is due to set up a limited liability company and held amendment shall be made by notarial deed as a primary requirement. The requirements in accordance with the provisions of Article 7 Paragraph (1) of the Company Law and Article 21 Paragraph (4) of the Company Law. Based on the wording of Article, notarization is absolutely necessary and must be met to establish and to change the articles of association of a company, an authentic deed is a deed that is required to be made in a notarial deed in Indonesian.

In Act No. 30 of 2004 as amended by Act No. 2 of 2014 concerning Notary (hereinafter referred UUJN). According to Article 1, paragraph 1 UUJN mentioned that the Notary has no place as a public official authorized to make an authentic deed and other authorities referred to in this Act. $^{2}$ In creating an authentic deed, a notary has authority and responsibilities of the deeds that have been made by him where the deed can be written evidence and have the authentic nature of the parties.

Legal certainty into the spirit of the economy, particularly with respect to the owners and users of big capital (macroeconomic). The complexity of the work and problems faced by owners and users of capital higher, because of the risks they face are also

\footnotetext{
${ }^{1}$ Fuady, Munir. (2010). Perseroan Terbatas Paradigma Baru: Bandung: Citra Aditya Bakti. p.1

${ }^{2}$ Act No. 2 of 2014 concerning Notary
} 
getting bigger, so it needs the legal certainty of the presence of a notary deed made authentic. $^{3}$

Notary has a duty to ensure that what is contained in the deed of Notary truly understood and as desired by the parties, that is the way to read it so clear the contents of the deed, as well as provide access to information, including access to legislation that Related to the parties signing the deed. Therefore, the parties are free to determine the contents of the deed for agreeing to be signed. ${ }^{4}$

Position Notary as a public official has the authority to make the authentic act one of which is a deed Establishment and Amendment of Articles of Association of the Company Limited at the request of the founders and administrators which must be incorporated in the form of an authentic deed that aims to organize all sorts of rights and obligations of the founders Company in managing and running the company. In the authentic act a clear determination of rights and obligations, will guarantee legal certainty and is expected to avoid disputes. Although the dispute is unavoidable and in the dispute settlement process of the authentic act can be legitimately written evidence in dispute resolution.

In accordance with the Article 21 Paragraph (4) of the Company Law which states that allow PKR deed made by the notary as an authentic deed. In the event of a formal defect in the deed then the deed only has the strength of evidence like a deed under the hand when the parties signed the deed. Notary liable only to the extent the data is entered or taken by the minutes of the AGM.

One of the cases that can be used as an example here is a case of Statement of Shareholders' General Meeting to change the articles of association of a company as defined in the Company Law Article 21 paragraph (4) on the basis of the Minutes of the Meeting or of Resolution of the parties and authorize one company to attend on Notary to state once again the results of the meeting in notary deed.

Based on the background as described above, it can be formulated an issue of how the Authority Notaries in Deed of Amendment will create a limited liability company by using the Minutes of the general meeting of shareholders which was not attended by the Notary, as well as how the legal consequences and legal protection Notary deed of amendment to the PT based solely on the Minutes.

\section{Research Methods}

The approach in this research is legislation (Statute Approach), in this method the researchers studied the written rules contain legal norms binding in general and formed or defined by state agencies or competent authorities through the procedure

\footnotetext{
${ }^{3}$ Handoko, Widhi. (2019). Dominasi Negara Terhadap Profesi Notaris Antara Ide Dan Realita, First Edition. Bogor: Roda Publika Kreasi. p. 36

${ }^{4}$ Elucidation of Act No. 2 of 2014 concerning Notary
} 
laid down in legislation in the form of legislation and regulation. The law used in this research include Act No. 2 of 2014 On Notary particularly refers more to the Authority and Duties of the Notary contained in Article 15 and Article 16 of Act No. 40 of 2007 on Limited Liability Company.

\section{Results and Discussion}

\subsection{Position and responsibility of the Notary Deed General Meeting of Shareholders} on the basis of a company's budget changes

Making the agreement in written form can be understood as a form of the desire of the people who make it to give birth to the evidence. The most notable difference in making this evidence is an authentic act would be perfect evidence, so that the authentic act has the power proving a stronger and more extensive than the deed made under the hand.

Deed of the General Meeting of Shareholders of the Company Limited, is a notary deed of Notary as a public official who is authorized to make, the deed appears based on the will of the parties to ask for as a necessity in the world of practice. In the Limited Liability Company Act a result of the AGM can be made in each of the authentic act or under the hand. Given that not all the AGM was made in an authentic deed the organ of a company sometimes do the AGM without the presence of a Notary Public, but then, to reinforce the results of the organ company AGM will authorize one of the directors to pour the AGM decision in an authentic deed. ${ }^{6}$

Role and responsibilities of notaries in the manufacture of the Deed of General Meeting of Shareholders of the Company are?:

a. Ensure the certainty of the date, the signature of the deed he had made;

b. Client must actually be present before a notary;

c. Read out the contents of the deed;

d. Signer certificates on the day and date as mentioned in the deed;

e. Signer certificates in the territory of the notary office;

f. Minuta save the deed;

g. Provide a copy of the deed;

\footnotetext{
${ }^{5}$ Marzuki, Peter Mahmud. (2005). Penelitian Hukum. Jakarta: Kencana. p.137

${ }^{6}$ Interviews with Tri Wahyu, Notary in Cilacap, on November 13, 2019

${ }^{7}$ Widyawati, \& Handoko, Widhi. (2018). The Notary Role / PPAT in Improving Legal Awareness Society to Perform Registration Rights to Land Based on Government Regulation No. 24 of 1997 on Land Registration. JURNAL AKTA: Vol. 5, No. 4, 975-980. Retrieved from http://jurnal.unissula.ac.id/index.php/akta/article/view/4127
} 
h. Take note of any deed that made in a book list deed;

i. Send a copy of the deed to the Assembly Regional Supervising Notary, every month no later than the $15^{\text {th }}$ of the following month.

Deed of the General Meeting of Shareholders can be understood, as the foundry GMS under the hand into an authentic deed. Notary in this case is not involved in the decision-making AGM is made under the arm, but the decision is made by the parties to the agreement on the basis of their agreement. Then the letter or the agreement is brought before a notary, to be poured into an authentic deed.

Thus, in the manufacture of the Deed of General Meeting of Shareholders, the responsibilities of a notary deed is very limited as Partij. While the validity of the material or the content of the agreement and all the legal consequences that arise from, the notary can not be prosecuted and held accountable, it is entirely the responsibility of the parties to make such an agreement.

\subsection{Effects Public Notary Deed on Shareholders of the Company}

General Meeting of Shareholders of the Company are made under the hand and then poured into an authentic deed, will take legal effect, ie the certificate become an authentic deed.

Deed under the hands of the judge is "Free Proof" (VRU Bewijs) because the deed under the hand of this new material evidence after the power has proven formality strength. Moderate strength of evidence of new formality occur, unless the parties concerned acknowledge the truth of the content and the way it's deed. Thus, the deed under different hands on an authentic deed, because when the deed under the hand is declared false, then using the deed under the hand as evidence must prove that the deed was not a forgery.

Nevertheless authentic act or deed made under the hand remains a treaty, as defined in the Civil Code, so it can be binding on the parties who made it all eligible invalid an agreement.

An agreement is valid if it has met the conditions specified legislation, so that the existence of such agreements is recognized by law. Terms of validity of the agreement can be seen in Article 1320 of the Civil Code, namely:
a. Ada agreed they were bound themselves;
b. There is an ability to make an engagement;
c. There is a particular case; 
d. There is something that is lawful reasons.

Dari above description, it can be seen that a result a decision general meeting of shareholders limited liability company created under the hand will be an authentic act, in which the authentic act is perfect evidence.

The authentic act or letter under the hand is a tool written evidence as referred to in Article 1866 of the Civil Code. The proof with sign writing is something that can be read and stating a piece of mind. The article can be deed and deed in writing. Deed is written specifically made to be used as evidence on matters referred to therein.

The certificate is subdivided, namely the authentic act and deed under hand. Under Section 1868, the authentic act is an act which is in the form prescribed by law, made by or in the presence of public officials who are authorized to it in a place where the deed was made. Regarding the deed under the hand, there is a provision in Article 1844 which states that the deed under the hand is writing signed without intermediary public officials.

Regarding the strength of evidence a written evidence to do division into 3 types of strength of evidence, namely: ${ }^{9}$

a. The strength of evidence extern;

b. Formal proof strength;

c. The strength of evidence material.

The strength of evidence extern, meaning that if a deed of his form just seemed to be a deed made by a public official, the deed as it is regarded as an authentic deed. Extern strength of evidence that apply to everyone. Strength formal proof, this means that what is referred to in a deed it was true what was described by the parties concerned and this holds true for anyone.

The strength of evidence material, this means that what is contained in a deed that is really happening between the parties (so not only spoken only by the parties, but also indeed did happen).

With the 3 types of powers that can be reviewed evidence proving the strength of what is contained in each proof by writing. In deed there authentic extern strength of evidence for an authentic deed must have a specific form defined by the legislation of which makes it is a public official. Extern strength of evidence was not only apply to those referred to in the deed with it, but it also applies to every person. Who would deny that the deed should proof the mistaken. The falsity of a deed can be divided among the falsity of material and intellectual falsity.

\footnotetext{
${ }^{8}$ Afandi, Ali. Hukum Waris, Hukum Keluarga, Hukum Pembuktian. Jakarta: Rineka Cipta. p.199 ${ }^{9}$ lbid.
} 
The falsity of material occurs if the signature or written in the deed was forged after the deed was made by public officials. While intellectual falsity turns when the official deed incorrect information included in the deed.

Thus, in the authentic deed that sure is true, is the signature of the parties concerned, the date, the place where the deed was made.

Because in the deed under the hand other than the signatures also include the date, then on this date there are provisions in Article 1880 which states that the third party liability that date will be accepted as the true start:

a. Date deed was inaugurated (notaries, other officials according to law);

b. Date where the sign it was dead;

c. Date of another deed that calls the deed;

d. Date where the third party acknowledges the deed earlier.

So, in this case the deed under the hand was recognized, then the deed under the hand and no real authentic act is no difference on the strength of evidence.

\subsection{Legal Protection for Notary Deed In Making General Meeting of Shareholders of the Company Limited}

Everything is done by any individual who is part of a social society will not escape from responsibility. Whoever and wherever existence is good to be, is being or has been done can not be separated from responsibility. Basically everything is done by one either intentionally or not, should be held accountable especially relating to professional ethics of a professional in the field of law.

The heavy responsibility placed on the shoulders of members of the legal profession, when concerning the protection of one's fate. It is not just about personal interests, but also common interests. The responsibility should be imposed on a legal profession in performing their duties and positions the profession is not light. Therefore, to the responsibilities of the legal profession required a clear scope, so all he has done for his position can be justified.

Accountability for one's actions usually there is a new practical sense, if the individual acts that are not allowed by law and the majority of acts like this is an act in the Civil Code named by tort (onrechtmatige daad). ${ }^{10}$

\footnotetext{
${ }^{10}$ Prodjodikoro, R. Wirjono. (1983). Asas-asas Hukum Perdata. Print. 9. Bandung: Sumur. p.80
} 
Onrechtmatige daad or tort stipulated in the Civil Code Book III Chapter III of the engagements is born for the sake of the law, Article 1365 to Article 1380. As for the sound of Article 1365 of the Civil Code is "Every illegal acts that bring harm to another it requires people because it hurts publish losses, replace the losses."

Based on the foregoing, it can be argued elements are as follows:
a. The existence of an act;
b. The act was unlawful;
c. An error of the perpetrator;
d. The loss to the victim;
e. The causal relationships between actions and loss.

Based on the above opinion, if it is linked with the profession Notary, it can be said that if the notary in the running of their office intentionally perform an act that is detrimental to one or both sides facing in the preparation of a deed and it really knowledgeable, that something is done by a Notary for instance contrary to the law, the Notary can be held accountable under Article 1365 of the Civil Code. Likewise, if a Notary whose duties also provide services to the public or people who need his service in the ratification or the creation of a deed, then in the deed contained a clause to the contrary, for example by law, causing losses to others, while the parties are facing not even know it, then with the silent passivity or Notary concerned can apply Article 1365 of the Civil Code. Notary who committed an unlawful act can be submitted to the court, then when an unlawful act can be proved, then the notary shall pay compensation to the injured party.

All legal regulations actually aimed toward the balance of different interests, because of legal regulations simply the result of human actions and a human is to be imperfect, then of course all legal regulations it contains the imperfect nature anyway. If this is associated with the profession of a Notary, the Notary is basically in the line of duty, his position can only make a mistake or that a civil offense it may be requested a liability, although it relates to the material truth of the deed before him.

Notary who commits an offense in the deed of the parties, can not be sued by default, but can be sued by an unlawful act. It also said that in deed made before him, a notary is not one or the party to the deed made it, because the deed is a deed of those who came before. Despite the mistakes made by the Notary in deed, it does not mean 
notary are in default to the client who came before, for the manufacture of Partij Akten not on an agreement between the parties and the Notary, but rather an obligation born of the command laws against Notary them. The authenticity of material in Partij Akten, if something goes wrong or contrary to the actual stated in the deed. ${ }^{11}$

This can occur if the relevant Notary has done its job and determine based on science and the nature of its prudence. If the Notaries make a mistake or negligence in the manufacture of such deed, the deed made against it can be null and void or may be requested cancellation.

Based on the results of interviews with the Notary can be explained, that Notaries should be accountable to civil and claims it is based on tort. It mean though Notaries just constantire intent of the parties are facing, it does not mean Notary never or impossible to perform actions contrary to the provisions of the law, because in practice it is too much going on.

Everything is done by any person to cause harm to another person, can be sued. A tort committed by notaries who cause harm to his client, can be snared by Article 1365 of the Civil Code and as for the purpose of Article 1365 of the Civil Code, the fact is return patients were harmed in its original state, at least in circumstances that might be achieved in case tort does not happen, then it will be endeavored real returns that would be more appropriate than the payment of compensation in the form of money, for payment in cash only equivalent value only.

\section{Closing}

Notary authorized to make the authentic act on all deeds, agreements, and provisions required by legislation and / or desired by the stakeholders to be stated in the certificate is authentic, guaranteeing the creation date of the deed, saving certificates, giving grosse, copy, and official copies all of it throughout the manufacture of the deed was not also be assigned or excluded to other officials or any other person specified by law. In the manufacture of the Deed of General Meeting of Shareholders a limited liability company, a notary is expected to seriously pay attention to all the provisions of the relevant legislation to avoid legal problems later on. To the parties that made the letter, you should first explain the legal consequences of the deed. Given the basis of a deed meeting decision statement of a limited liability company, is a meeting minutes which is a letter under the hand, that the manufacturing process was not attended by a Notary. It is very different to the General Meeting of Shareholders Limited generated deed, where notaries are required to attend and follow the process of implementation and then poured into an authentic deed.

\footnotetext{
${ }^{11}$ Djojodirojo, M.A. Moegni. (1979). Perbuatan Melawan Hukum. Jakarta: Pradnya Paramita. p.102
} 


\section{References}

Journal:

Widyawati, \& Handoko, Widhi. (2018). The Notary Role/PPAT in Improving Legal Awareness Society to Perform Registration Rights to Land Based on Government Regulation No. 24 of 1997 on Land Registration. JURNAL AKTA: Vol. 5, No. 4, 975-980. Retrieved from http://jurnal.unissula.ac.id/index.php/akta/article/view/4127

Books:

[1] Afandi, Ali. Hukum Waris, Hukum Keluarga, Hukum Pembuktian. Jakarta: Rineka Cipta

[2] Djojodirojo, M.A. Moegni. (1979). Perbuatan Melawan Hukum. Jakarta: Pradnya Paramita

[3] Fuady, Munir. (2010). Perseroan Terbatas Paradigma Baru: Bandung: Citra Aditya Bakti

[4] Handoko, Widhi. (2019). Dominasi Negara Terhadap Profesi Notaris Antara Ide Dan Realita, First Edition. Bogor: Roda Publika Kreasi

[5] Marzuki, Peter Mahmud. (2005). Penelitian Hukum. Jakarta: Kencana

[6] Prodjodikoro, R. Wirjono. (1983). Asas-asas Hukum Perdata. Print. 9. Bandung: Sumur

Regulations:

[1] Act No. 2 of 2014 concerning Notary

[2] Elucidation of Act No. 2 of 2014 concerning Notary

Interview:

Interview with Tri Wahyu, Notary in Cilacap, on November 13, 2019 